\title{
Evil, Feminism and a Philosophy of Transformation
}

\section{Position Paper, Melbourne, July 2014}

\section{Introduction: Shifting the Ground}

There's an old joke - a very old joke - which describes fittingly the stance on evil to be taken in this paper. Some townies are lost in the deepest English countryside. Waving down a local, they ask for directions. The response to their query is not immediately helpful: 'if that's the place you are looking for, I wouldn't start from here, if I were you.'

I want to make a similar response - albeit, I hope, in the long run more helpful - to those engaged in the form of discourse which dominates discussion of evil in the philosophy of religion. As anti-theodicists have been at pains to point out (Phillips 1988; Surin 1986; Tilley 1991), these arguments revolve around an assumption of evil as a puzzle that needs to be solved. Rarely is the problem of evil approached in such a way as to provide reasons that would satisfy those struggling with the livedexperience of suffering, either as the result of natural forces or the actions of others. ${ }^{1}$

While my starting point is not dissimilar to that of the anti-theodicist, my concern is not to expose in any more detail the irrelevance of the answers offered by theodicists for those struggling with the felt affects of evil or the experience of suffering. ${ }^{2}$ The aspect I wish to pursue here relates to something hinted at in Kenneth Surin's

\footnotetext{
${ }^{1}$ That the anti-theodicist arguments have found their mark is suggested by Eleanor Stump's recent use of narrative to explore the issue of suffering and the kind of defence of God that might be made in light of its reality (Stump 2010).

${ }^{2}$ While we might well argue that evil and suffering are separate issues - the former dealing with metaphysical questions of the nature of the universe, the latter with the lived-experience of evils, natural and moral - in practice the two categories are invariably blurred in the discussions of philosophers and theodicists.
} 
discussion of theodicy: namely, that unintended consequences may arise from pursuing theodical arguments (Surin 1986: 154-163). In the attempt to form detached and purportedly objective responses to the problem, theodicists run the risk of dulling their senses - moral and emotional - to the very real suffering of individuals and communities. ${ }^{3}$ My concern is to consider a response to evil that might move beyond this claim. How might an account of the sources of evil and suffering be made that enables better ways of living to emerge? As such, the discussion of evil that follows locates the problem in the realm of ethics, my contention being that it is only by sodoing that we are able to avoid the problems anti-theodicists have identified with the intellectual pursuit of evil.

It is worth spending a little time on this reframing of the problem as it raises more general questions about what philosophy as a discipline can or cannot achieve. When a philosopher approaches the problem of evil, they do so with a particular aim in mind. For some, the concern will be to provide a possible 'solution' to the problem: ${ }^{4}$ and this may well involve making distinctions between the 'logical' and the 'emotive' (or experiential or evidential) problem of evil. They may have a particular tradition in mind, and may be addressing the problem in order to establish a convincing theological apologetic. Whatever the aim, something much more fundamental is at work, for the way in which evil is approached reveals much about the way in which the very practice of philosophy is understood.

\footnotetext{
${ }^{3}$ Surin's approach reflects, similarly, that of Jürgen Moltmann: the way in which we construct our image of God has an impact on the way in which we structure our relationships with others. So for Moltmann, advocating divine apatheia cultivates apathy in the response - or lack of it - that might be made to those suffering (1974: 267-278).

${ }^{4}$ I am not convinced by the turn, inspired by Alvin Plantinga (1977), and developed by philosophers such as Stump (2010: 19-20), that there is a real difference between offering a 'complete' theodicy and a 'partial' defence. The focus remains on solving - or at least going some way to solve - a problem for God, rather than ameliorating the experience of suffering (see Clack 2005).
} 
In the analytic tradition, the practice of philosophy involves the analysis and criticism of language; it involves aligning oneself - as closely as possible - to the methods and practices of science. Its detractors have been similarly certain about what philosophy involves, and have consistently - and insistently - pointed to the failure of philosophers to engage with the questions of 'real life'. For Paul Ricoeur's 'Masters of Suspicion', this failure leads to the conclusion that philosophical practice is an irrelevance. Thus for Freud, the desire to practice philosophy reflects a melancholic disposition that seeks answers to questions that could never be answered (Freud 1960: 436), while detracting from the much more realistic and worthwhile work of empirical scientific investigation (Freud 1916-17: 20). For Nietzsche, it denotes the failure to say 'yes’ to life (Gay Science $§ 327 ; 2001: 182-3$ ). This criticism leads Nietzsche to frame his 'gay science' as a means of changing the values of the old world to this affirmation of life; be it through dancing with Dionysus ( $G S \S 381 ; 2001: 246)$ or through 'philosophising with a hammer' (Nietzsche [1889] 1990). For Marx, what matters is engaging in practical politics: "the philosophers have only interpreted the world, in various ways; the point is to change it" (Marx 1845: 184).

In suggesting an ethical focus for the discussion of evil, I am aligning myself with aspects of those critiques: most notably with the emphasis placed by Marx and Nietzsche on the kind of practice most likely to bring about transformation, of one's self and of the world. ${ }^{5}$ That does not mean, however, that I intend to accept their rather pessimistic vision of what philosophy can - or rather, cannot - achieve. I do not

\footnotetext{
${ }^{5}$ In asserting the transformative nature of philosophical practice, I am building upon Michael McGhee's formulation of philosophy as spiritual practice (McGhee 2000).
} 
accept that philosophy is, by its very nature, a practice disengaged from the everyday task of living. Indeed, by aligning philosophy of religion with ethics, and approaching the discussion of evil in this way, I believe it is possible to show something of the importance of critical religious thought and practice for how we might live. ${ }^{6}$

In shaping an ethical approach to the problem, the insights of feminist philosophers of religion are invaluable: not least because the political dimension is central to feminist theorising. For the feminist to discuss evil and suffering necessitates considering the questions it raises for our life together; for the feminist philosopher, it raises questions about the way in which philosophical discussions affect the way we act in the world. This makes an engagement with practical politics impossible to avoid and leads me to frame the argument of this paper in the following way: is it possible to shape a philosophy of evil capable of enabling the kind of life that supports human flourishing? (And in emphasising human flourishing, I understand that notion to involve not just the life of the individual, but also, crucially, the shape of the political and social realm. ${ }^{7}$ )

In framing the discussion in this way, I am indebted to the insights of Mary Midgley. In her innovative investigation of wickedness ([1984] 2001), Midgley directs attention away from insolvable and unknowable debates about God and metaphysics, towards the much more practical task of trying to understand the sources of human wickedness. For Midgley, the discussion of evil is primarily an ethical one, for it

\footnotetext{
${ }^{6}$ It says much about the dominance of one way of proceeding in the Anglo-American philosophy of the $20^{\text {th }}$ century that this view of philosophy can appear rather novel. As Martha Nussbaum (1996) amongst others has shown, this vision of a philosophy that might be able to ameliorate the experience of suffering (to paraphrase Epicurus) shapes the earliest forms of the discipline.

${ }^{7}$ Here I am indebted to the work of Grace Jantzen whose feminist philosophy of religion was explicitly structured around the promotion of human flourishing (Jantzen 1998).
} 
raises questions of how it might be resisted, as well as forcing us to consider the nature of the good life.

To approach evil as a problem for human beings rather than for God raises questions about the contribution that can be made by the philosophy of religion. My hope is that approaching evil in this way allows for a fresh appreciation of why religious perspectives might be helpful for engaging with this most pressing of concerns.

\section{Identifying Evil: The Contribution of Feminist Analysis}

In suggesting that the problem of evil be framed primarily as an ethical issue, I understand 'the ethical' to denote both the way in which social relationships are shaped by political structures, and the way in which personal relationships are conducted. Moreover, in pursuing an ethical approach to evil, I want to suggest the importance of one's orientation to the world, for it is here that the practice of philosophy of religion proves significant.

In order to make this shift towards the ethical, it is necessary to start with an element often lacking in the analyses of evil offered by philosophers of religion: the social and political context for personal relationships. To even get close to understanding the sources of evil, it is vital to consider the social locatedness of the human subject, and here feminist philosophy provides an important starting point: not least because it allows for examination of the ideas that support social and political life.

Feminist philosophy connects critical analysis with practical, political action; a connection which holds out the prospect of transforming academic discussions of evil. 
While there may be different feminisms, each reflecting different theoretical positions, ${ }^{8}$ they share a common concern to expose and correct the marginalisation of women's lives and experiences, and to address gender injustice. And feminist philosophy, as Gillian Howie points out, is explicit about an implicit feature of all philosophy: namely that "every philosophy is practical, even when it seems at its most contemplative: its method a social and political weapon" (2012: 9).

That feminism arose out of women's struggles to be recognised as 'fully human' - to use Rosemary Ruether's memorable phrase (1983: 18) - inevitably means that, far from being a distraction, the discussion of evil is at the heart of the feminist commitment to changing the world. To locate the discussion of evil in a political movement for change necessitates considering the way in which 'evil' is defined. For the feminist, concerned with identifying and resisting gender injustice, the issue of moral evil takes priority. (Indeed, for the vast majority of feminists - and specifically for ecofeminists - the notion of physical or 'natural' evil is a misnomer. The natural processes which make human life possible cannot be described as 'evil' even if their affects are felt in human suffering (Plumwood 1993). This is an idea with an ancient pedigree: when Seneca writes on the propriety of natural processes, he is at pains to conclude that if you don't like the suffering that accompanies life in this world, that's your problem. Such experiences, he says bluntly, are the price we pay for the privilege of being alive (Letter XCI; 1969: 181-2).)

In making their focus the exposure of injustice, feminists expand the very notion of what counts as 'evil' to include not just individual moral failures but its socially-

\footnotetext{
${ }^{8}$ For a brief description of these differences, see Clack 2013: 326-328.
} 
embedded manifestations. As Sharon Welch and others note, to understand injustice, its enactment and perpetuation through political and social structures has to be addressed (Welch 1989). To describe the way in which these interlocking structures allow oppressive practices to be enacted and enshrined in personal relationships, they use the term 'structural evils'.

We might at this point question the propriety of using the term 'evil', accepting, with Midgley, that we are better advised to employ, instead, the terms 'wickedness' or 'injustice'. It is, however, powerful to name something 'an evil'. Something about the very word demands we take seriously things that are 'out of joint'; that an attitude or an event or a history is so wrong that we must act to 'put things right'. In drawing attention to structural evils, the feminist demand is that we seek ways of challenging and changing such structures. At the same time, extending the notion of what constitutes evil does something more: it alerts us to the fact that what is meant by 'evil' is not self-evident. Ideological commitments are reflected in the definitions which are offered. There is no purely objective stance to be taken to this work of definition: ideas are never 'innocent', for they reflect our starting point but also, crucially, they shape the way in which the world is conceived and society structured.

Exploring the relationship between ideas and social practice formed a large part of the work of early feminist philosophical analysis which centred on exposing the way in which definitions of 'Woman' shaped the exclusion of women from the public realm. So Genevieve Lloyd (1984) and Susan Moller Okin (1979) were at pains to expose the unacknowledged history of misogyny in Western philosophical and religious thought. Building upon Simone de Beauvoir's contention that gender is not a given, 
but is constructed over time by family, social and historical assumptions (Beauvoir [1949] 1972), they detailed the historical constructions of 'Woman' as that which stood in opposition to the values claimed by the male.

Realising the amount of energy spent by past philosophers and theologians on defining 'Woman' can come as something of a surprise. ${ }^{9}$ Even more surprising can be the realisation that their 'findings' all-too-frequently identify women with 'evil'. An example: if Aristotle viewed the female as essentially passive matter to be shaped by the active male (in Clack 1999: 31-36), this notion was developed by Aquinas to claim that Woman is fundamentally flawed; she is, in his words, a "defective male" (in Clack 1999: 77). For medieval theologians concerned with the phenomenon of witchcraft, the 'fact' that Woman is ontologically flawed makes women the perfect conduit for evil. When Kramer and Sprenger write their handbook for witch-finders in the $15^{\text {th }}$ century, it is not surprising that, as a result, they view women as peculiarly linked to that which is evil. Evil entered the world through a woman: a process which did not end there but which is continued in the actions of all women, cast as her daughters (in Clack 1999: 89).

If women are defined as, at worst, incapable of goodness, at best, limited in their ability to pursue the moral life, practical measures will be deemed necessary to curb their influence. To define women as evil is not, then, to partake in whimsical

\footnotetext{
${ }^{9}$ My Misogyny in the Western Philosophical Tradition: A Reader (1999) resulted from the shocked realisation that western philosophers and theologians had spent an inordinate amount of time engaging with the question of 'who woman was' and what it was that 'she' wanted'. Becoming conscious of the extent to which 'Woman' had been considered an object to be studied radically challenged my sense of philosophy as a neutral and objective practice: rather its history and its categories reflected the social positioning of one group: usually white, usually affluent, males.
} 
reflections that have little bearing on lived relationships; indeed, such notions were

felt in social practices which constrained the lives of generations of women. ${ }^{10}$

The task for the feminist philosopher of religion, confronted with such a history, is to expose the theological and philosophical basis - both then and now - for legitimising gender injustice. To paraphrase Marx, the role of critique is to tear up the illusions that justify oppression (1844: 171). The analysis of ideas, as a result, is not simply for the sake of analysis alone. Analysing ideas and their affects has the power to challenge social injustice, for the critical function of philosophical practice is not an end in itself, but provides the groundwork for changing unjust social conditions.

\section{Social Structures, Evils and Human Suffering}

It is relatively easy to frame philosophy as a critical practice which challenges assumptions; even as a practice that alters the way in which individuals might be encouraged to modify their attitudes and behaviours. We might think, for example, of the role of the 'spiritual exercise' to bring about change in the attitudes and behaviour of the individual, as described by Martha Nussbaum (1996) and Pierre Hadot (1995) in their accounts of the Hellenistic Schools. But can critique transform social

\footnotetext{
${ }^{10}$ For a classic account of the history of misogyny, see Marilyn French 1992. While we might like to think that such days are long gone, claims of female fallibility continue to inform debates about the unequal numbers of men and women in public life and leadership roles. Recent discussion highlights the problems of a male-dominated political elite. In the UK, a cross-party inquiry has been set up to consider why many women MPs are stepping down at the next election: 'MPs call for action to keep more women in politics, Daily Telegraph (9 February 2014)

http://www.telegraph.co.uk/news/politics/conservative/10626637/MPs-call-for-action-to-keep-morewomen-in-politics.html. It may not be so hard to understand, a female MP reporting her experience of being barracked for having a northern accent http://www.independent.co.uk/news/uk/politics/toriesdeliberately-mock-women-mps-for-their-northern-accents-says-pat-glass-9133437.html. Arguments that women need to 'toughen up' in the face of such treatment - often expressed by women - suggest the extent to which claims of female weakness permeate the political world. Rather than challenge the way in which politics is conducted, this response suggests the problem lies with women for wanting to change it. http://www.telegraph.co.uk/women/womens-politics/10649213/Former-Tory-MPs-If-thesesilly-modern-female-MPs-cant-cope-they-shouldnt-be-there.html
} 
practices? If the Masters of Suspicion claim too little for philosophy, am I claiming too much?

Hannah Arendt's work suggests that this kind of socially-engaged, transformative philosophy is a very real possibility for philosophical practice: but only if we challenge entrenched assumptions about what 'philosophy' involves. Like Nietzsche, Marx and Freud, Arendt is sceptical of the extent to which philosophy can be of use to the practical task of shaping the public realm. "Burdened by tradition"11, philosophers cannot easily respond to the plurality of positions that characterises her vision of the kind of public space we should aim to create; a vision that is, to her mind, most conducive to the flourishing of individuals. ${ }^{12}$

Yet her depiction of thought as a disruptive practice provides a helpful framework for integrating theory and practice in such a way that philosophy can be part of the process by which social change is brought about. In Arendt's philosophy is the groundwork for an ethical approach to the problem of evil which illuminates the possibility of effecting personal and social transformation.

Arendt is doubtless best known for her report of the trial of the Nazi war criminal Adolf Eichmann for the New Yorker Magazine. Eichmann could not have looked less like the popular image of a war criminal: he was a shabby little bureaucrat, not a

\footnotetext{
${ }^{11}$ This comment is taken from a conversation with Günter Gaus, in Baehr 2000: 4.

${ }^{12}$ Arendt also raises the question of the political failure of philosophers to identify injustice as injustice; the most obvious case being found in Arendt's mentor and erstwhile lover Heidegger's inability to see Nazism as something to be resisted not accepted. As Dana Villa describes it, in Heidegger there is found "the 'strange alliance' between philosophy and thoughtlessness" (Villa 1996: 192). Abstract thought of the kind in which Heidegger excelled means little if there is no "care for the world" (Villa 1996: 192).
} 
monstrous presence of evil. As she attempts to understand him, she arrives at her famous description of 'the banality of evil'. ${ }^{13}$ Eichmann is troubling because he is so ordinary, and, in framing the evil he represents as 'banal', Arendt refuses to set him apart from the rest of humanity. If anything, he is an example of what she describes as a "new type of criminal" (1964: 276), whose crimes emerge from a particular set of social conditions and working practices. Far from being a monster, he exhibits attitudes and behaviours common to many. In developing this analysis, Arendt makes a compelling case for linking social and political structures with the creation of individual attitudes, and thus raises the importance of embarking on forms of action that enable the transformation of both.

Arendt begins with an analysis of the structures that support oppression and the perpetration of destructive acts. To understand Eichmann, he must be placed in the context of the twentieth century's burgeoning dependence upon bureaucratic systems for structuring the state and shaping human behaviour. The roots of this phenomenon are first set out in her Origins of Totalitarianism ([1951] 1968), before being taken up once more in her report on the Eichmann trial.

Arendt claims that bureaucracies enable the flourishing of individuals like Eichmann: individuals who are rendered incapable of associating their particular, isolated tasks with the broader agenda of their employers through the working practices of their institution. Bureaucracies operate on the basis that a prescribed end can be achieved through the implementation of rules and procedures (Weber 1947). Such systems give

\footnotetext{
${ }^{13}$ Richard J Bernstein offers a fine account of Arendt's conception of evil which includes reflections on the controversy surrounding and the critique of her notion of banality (2002: 205-235).
} 
the appearance of being 'rational' and easy to manage in comparison with the messy reality of dealing with idiosyncratic and apparently 'irrational' individuals. While there might be some truth in this, the effect of such a judgement is that the human realm, made up of such individuals, and thus beset with uncertainty, becomes characterised as less trustworthy than 'the system' itself.

If human relationships are disparaged in this way, bureaucratic states require the worker to limit their understanding of the scope of their work to the specific task with which they are engaged. For a worker to succeed in such a workplace, they must become "a mere function" of the organisation (1968: 215), 'aloof' from ordinary human concerns that might obscure the focus on achieving the prescribed social ends. ${ }^{14}$ To be successful as a function necessitates resisting the kind of thoughtfulness that would connect one's actions to effects felt in the lives of others. ${ }^{15}$

In such a context, Eichmann becomes a rather successful example of a bureaucrat. This dull little man surprised Arendt because he was, if anything, all-too-familiar; not that different from the kind of administrator who might encountered anywhere, whose job is similarly fragmented, focused on specific tasks which are, in turn, detached from the broader aims of their organisation.

\footnotetext{
${ }^{14}$ Arendt identifies this ideal in the methods of administration and the promotion of this kind of administrator in the structures developed by the British to effectively manage their Empire (1968: 212). ${ }^{15}$ A current example might be the number of reports suggesting that UK Job Centres are setting targets for sanctioning benefits claimants, thus enabling a culture of intimidation - both for claimants and Job Centre staff http://www.theguardian.com/society/2013/mar/25/jobcentre-newsletter-sanctions-targets. While these claims have been rejected by the UK Department of Work and Pensions, such claims continue to be made: http://politicalscrapbook.net/2014/02/jobcentre-awarded-staff-gold-stars-forsanctioning-claimants/
} 
Social practices therefore have an effect on the ethics of the individual, and her conclusion goes far beyond explaining the actions of one individual. To reiterate, Eichmann is a "new type of criminal...who commits his crimes under circumstances that make it well-nigh impossible for him to know or to feel that he is doing wrong" (Arendt 1964: 276). The modern workplace, shaped by bureaucratic systems, provides an ideal spawning ground for 'moral idiots' like Eichmann; people who become incapable of making the connection between their actions and the fate of others. It is thus thoughtlessness - understood as the failure to connect - that provides fertile ground for evil to flourish.

The philosopher of religion, intent on discovering the roots of evil, might not automatically turn their attention to the workplace. But for Arendt this is vital, for there is a connection between apparently neutral social structures and the effect they have on the actions of those who inhabit them. Expect the wicked to be monstrous and you are unlikely to recognise wickedness when it is being enacted (Midgley [1984] 2001: 4-5; 140). Indeed, for Arendt evil is able to flourish because of the kind of thoughtlessness demanded by specific working practices. In terms of how we proceed in our discussions of evil, there may be dangers for the theodicist who wishes to resist engaging with the problem of Auschwitz; ${ }^{16}$ but what Arendt suggests is that it is no less problematic to focus exclusively on "horrendous evils" (Adams 1999). To locate evil outside the realm of day-to-day activities runs the risk of divorcing it from

\footnotetext{
${ }^{16}$ See Stephen T Davis' attempt to do this (Davis 2001: 73-89), and John Roth's criticisms of such a move (Roth in Davis 2001: 97-101).
} 
the petty actions and failures that allow hideous acts of wickedness and injustice to flourish. $^{17}$

Arendt's example of Eichmann - while useful for making this shift from the extraordinary to the ordinary - might still act to obscure the relative ordinariness of the sources of evil. Eichmann's job, after all, was to ensure the trains ran on time to the death camps, and his claims to ignorance were undercut by the fact that he had been an eye-witness to mass murder (Arendt 1963: 87-90). A rather different example might prove helpful at this point; one which focuses on something small and apparently insignificant whose over-appreciation acts as a means of ignoring one's fundamental responsibilities to the other. In the process, we move some way towards thinking about how reflection on the sources of evil can be used to think seriously about what it means to live well.

Muriel Spark's novel The Girls of Slender Means opens with the line: "Long ago in 1945 all the nice people in England were poor, allowing for exceptions" (1963: 1). This opening sets the tone for what is, apparently, a light-hearted story of a group of genteel young women, rivals in love and for the use of a single designer gown. It ends as a much darker tale. An unexploded bomb, hidden in the garden of the hostel they inhabit, explodes, and a fire ensues. Caught in a tiny bathroom, there is a gap in a window that only the thinnest can negotiate in order to escape. Selina, having escaped, contrives a return. Nicholas - her lover - assumes "she had done this in an attempt to rescue one of the girls, or assist their escape through the window" (1963:

\footnotetext{
${ }^{17}$ See for example newspaper reports of a man whose disability benefit payments were cut, and who, it has been claimed, 'starved to death' as a result. http://www.mirror.co.uk/news/uk-news/disabled-markwood-starved-death-3194250
} 
122). Nothing could be further from the truth: she reappears clutching the muchfought-over dress, pushes passed the distressed girls who remain trapped, and exits once more through the window, pausing once she is safely outside to inspect "the condition of her salvaged item" (1963: 125). Saving the dress is the priority, not the imminent death of friends.

There is something shocking in Selina's action; something that reflects Arendt's banality of evil; the possibility of becoming desensitised to the things that really matter - friendship, love and compassion - while replacing them with the things that do not - material goods, money and status. As a result of his horror at Selina's actions, Nicholas takes holy orders, having "witnessed [an] action of savagery so extreme that it forced him involuntarily to make an entirely unaccustomed gesture, the signing of the cross upon himself" (1963: 60).

There is, of course, a direct relation, easily identifiable, between the callousness of this one individual and the suffering of her friends, left without hope and without comfort by someone from whom they might expect these things. In responding to this story, we might well console ourselves with the belief that we would not have behaved like Selina. More complex, perhaps, are to consider the connections between apparently abstract economic structures and the detrimental impact they have on the lives of others: particularly if we benefit from the inequalities enshrined by such structures.

The setting for Spark's novel is the 'Austerity Britain' of 1945 (see Kynaston 2007). The poverty of that time may not be felt by the rather genteel ladies of the May Tech 
Hostel in quite the same way as the majority of Britons at that time: Spark's girls are, after all, from the upper-middle and upper class. But that is not to say that the rationing of this period did not influence their actions: their fighting over a rare designer gown only makes sense against the backdrop of limited access to material goods. Indeed, Selina's selfish actions are framed in this context: she might well have behaved differently if surrounded by the material comforts expected in 'normal' times by someone of her class. ${ }^{18}$

This comment is not meant to absolve a spoilt girl of responsibility for her actions. We might feel uncomfortable if highlighting the social context for her actions leads us to this conclusion. At this point it is worth directing attention in a not-dissimilar way to the apparently abstract economic and social conditions which have similarly distorting effects upon our relationships with others.

Pierre Bourdieu's work on social suffering offers a way into a complex web of connections that are not easily identifiable and that may well prove unsettling if we like to think of our lives as relatively blameless ([1993] 1999). Bourdieu and his research team conducted interviews with a range of people from disadvantaged social backgrounds who were struggling to cope with "the distress caused by clashing interests, orientations, and lifestyles" (1999: 4). Reproduced in their entirety, these interviews allowed the voices of groups rarely heard to speak of their struggles and anxieties. Through these interviews, Bourdieu presents "the social macrocosm"

\footnotetext{
${ }^{18}$ In this sense Selina's actions could be interpreted through Bernard Williams' notion of 'moral luck' (Williams 1981: 20-39).
} 
(1999: 4) against which people live out their lives. Suffering is placed, as a result, within a 'social order'.

Bourdieu's analysis can make for uncomfortable reading for those of us whose lives benefit from unequal economic and social relations. As Bourdieu shows, tensions in personal and social relations are located in the experiences of unemployment, social change, and shifts in global industry and finance. As Bourdieu details the effects of global and social trends on the lives of individuals and families, it is difficult not to be reminded of the familiar language of 'restructuring', 'economic downturn', 'rationalising the work force' that pepper political discussion in today's own 'Age of Austerity'. The use of such abstract terms for describing economic conditions and their effect on working practices masks the extent to which such processes impact upon the lives of individuals and their social relations.

Spark and Bourdieu can be read, then, as extending Arendt's analysis in different, but interlocking, ways. Spark's story challenges us to reflect upon the way we conduct our own personal relationships; and particularly the things that get in the way of taking seriously the needs of the other. In Bourdieu's research, complex and easily ignored structural features are related to the day-to-day sufferings of people with whom we share social space. A socially-engaged philosophy will need to connect critical reflection upon our intimate, personal relationships with political critique. At the heart of a critique of this kind is the question central to the hermeneutics of suspicion proffered by Ricoeur's 'Masters of Suspicion': 'who benefits?' Asking that question may well reveal the extent to which we are far from blameless ourselves; that we are, in fact, beneficiaries of advantages built upon the sufferings of others. 
To consider the problem of evil as an ethical one necessitates, then, the kind of critical reflection that challenges both personal behaviour and social structures. At the heart of second wave feminism was the claim that 'the personal is political'. In order to address what Bourdieu tellingly describes as 'the weight of the world' experienced by many, the way in which we conduct our lives - personally and politically - must be at the heart of our enquiry. Critical reflection, grounded in social analysis, enables the disruption of assumptions and attitudes. It is this that allows for an approach to evil that holds out the possibility of transformation: of self and society.

\section{Philosophy of Religion and the Work of Transformation}

Identifying the conditions for evil is vital; but for the ethical dimension to become central requires responding to the challenge evil poses for human relationships. It is here that I turn explicitly to the philosophy of religion, for it is a discipline that can provide a creative space for enabling the work of personal and social transformation.

To recognise the complex web of personal and social connections that supports the perpetuation of suffering should not be the end of the process for an ethical philosophy. The next step to be taken is to turn our attention to the attitudes, behaviours and social structures that enable flourishing for the many, not just for the few. For social change that addresses the roots causes of evil to be affected requires a fundamental re-orientation of the self towards others and the world.

To re-orientate the self requires remaking relationships with others and the world. And it is the notion of re-orientation that is at the heart of religious theorising and 
practice. The very word 'religion' suggests something of this activity. There is a disputed definition which traces it to religare, meaning literally 'to bind'. This sums up neatly the most laudable of the desires that drive religious practice and belief. Religion involves the attempt to connect: with others and with the universe. To bind ourselves to others and the world means addressing the current structures of society as well as our daily lives together.

To re-orientate the self requires critical reflection: in Arendt's terms, it requires the cultivation of thoughtfulness. That philosophy of religion offers space for critical reflection is a point hardly worth making. Yet it is worth pausing for a moment to consider why this kind of critical thought matters. Michèle Le Doeuff, feminist philosopher and activist, poses the question in the following way:

We have to wonder what we are doing when we teach...Does our teaching have negative or supportive impact? Is it of any consequence for the future? For knowledge either breeds hope or crushes it when the past serves as a mirror of a desired future, or if one uses 'facts' to define and defend a norm for today and for the future. (Le Doeuff 2003: 82-83; my emphasis)

Because she is interested in the social effect of thought, Le Doeuff grounds critical reflection in the ordinary tasks of living, for here its transformative power can be felt. Critical thought, she argues, holds out the possibility of freeing the individual from what she calls the 'cognitive blockages' that ensnare them. She provides an example of what this means from her work as a feminist activist: 
A woman phones a domestic violence hotline: 'I'm calling because...my husband, no, no, he isn't violent, but I'm worried... I'm wondering whether he might become violent. Last night I didn't feel like having sex, and I said so. Then he got a knife from the kitchen, held it to my throat, and forced me to have sex like that. I think he might become violent.' It is quite usual for feminist centres to receive calls like this one, which both attest to the outrages inflicted on women and signal a kind of cognitive blockage. This woman was incapable of recognising violence for what it was, even when she was experiencing it. (Le Doeuff 2003: xv)

Enabling space for critical reflection allows for the sources of suffering to be identified in order that they are challenged. And for an effective challenge to be made, the practise of judgement is required: on the actions of others and, crucially, on ourselves (Midgley [1984] 2001: 49-73; 117-135).

Effective judgement requires resisting the desire to project all that is wrong out of the self and onto others. According to Melanie Klein, psychic development hinges on the movement between the 'paranoid-schizoid' and 'depressive' positions (Klein 1946). In the first stage of infant psychic development, the child learns to separate what is felt as evil from what is experienced as good; this is done by projecting onto the $\mathrm{m} /$ other all that is felt as bad. In the second stage, the child learns to take back both possibilities for evil and goodness into the self. This process - which Klein relates to maturity - suggests the importance of judging ourselves, our attitudes and our limitations. We must be self-critical, as well as critical of the societal structures and actions of others which support injustice. 
As Arendt and Midgley contend, the problem of evil can be addressed to some extent through cultivating this kind of critical self-awareness. Habitual behaviours - ours and others - can be challenged, and, as a result, different perspectives developed. Developing this way of thinking cannot be taken for granted; it must form part of our daily practice. Here, the significance of spiritual or religious practice comes to the fore. We might think of the Stoic understanding of philosophy as a form of spiritual exercise that enshrines attitudes towards life in this world (Hadot 1995). Alternatively, we might think of Bonhoeffer's claim that in a 'world come of age' Christian practice will consist 'only' of "prayer and righteous action" (Bonhoeffer [1953] 1971: 300). These claims emanate from widely different contexts but reflect broadly similar forms of practice. Reflective practice is not separate from how we live but connects our life with that of others, and necessitates living in such a way that we recognise our obligations to the other. What begins as a form of individual praxis, allows for the kind of activity capable of transforming the world.

Gillian Evans' study on educational failure and working class white children in Britain shows something of the possibilities open to this kind of socially-engaged critical reflection (2006). Evans' ethnographic research arose from her desire to understand the community of a housing estate in London's Bermondsey with whom she lived. Evans' analysis focuses on describing a complex web of social relationships - along with the political policies and school practices - that act to enshrine the experience of failure in the children of this estate.

The method she employs is fascinating. She describes her relationship with particular families; the practices of the local school; her developing relationship with the 
children who she is studying. She allows the experience to challenge her own attitudes and beliefs: often in uncomfortable and disturbing ways (Evans 2006: 4547). Ultimately, however, she goes beyond simply describing a set of social conditions, and offers concrete proposals for the kind of educational practices, rooted in an understanding of social conditions, which she believes would transform the experiences of children growing up on such estates. The possibility of changing society in very practical ways grows out of her work of critique. ${ }^{19}$

Now, we might say that this form of academic practice does not cohere with the aims of philosophy of religion; that philosophy of religion is primarily concerned with the analysis of ideas, not with the transformation of the political and social world. This is to ignore voices that suggest alternative models for the discipline: most notably, Grace Jantzen's re-visioning of philosophy of religion as a practice that enables the cultivation of flourishing. For Jantzen, the philosophy of religion should be re-framed as a form of practice that "enables the divine" (1998: 204). By this, she means creating a space for exploring themes that relate directly to the social world. And so she highlights the importance of considering what makes for trustworthy communities; how to affect justice for others; and how to create a sustainable relationship with the planet. To pursue such themes necessitates praxis as well as reflection. Philosophy of religion becomes a practice of living, not just a way of thinking. To pursue this socially-embedded vision of the subject enables a sense of its importance to emerge. It provides a context for identifying the things that hinder flourishing. But it has the potential to do more than this, encouraging the kind of connections that make for human flourishing.

\footnotetext{
${ }^{19}$ See especially Evans 2006: 158 for a synopsis of her proposals.
} 


\section{Conclusion: Evil and How to Live Well}

The problem of evil is at its most potent when it challenges the way we live. Its urgency is felt, not in the attempt to justify the ways of God to humans, but in the way it forces reflection on the conditions and attitudes that hinder human flourishing. ${ }^{20}$ Thinking critically about the conditions that make for injustice and that support the suffering of individuals and communities provides the basis for an engaged philosophy committed to seeking better ways of living for all. A critical philosophy does more than provide the context for the work of deconstruction: rigorous analysis enables forms of living to emerge which have the potential to transform the world of political and social relationships.

An approach to evil located in the area of ethics cannot avoid dealing with the affect that structures and practices have on individuals and communities. At the same time, it necessitates thinking seriously about the way in which our individual ways of living challenge or enshrine the kind of practices and attitudes that lead so many to experience life as harsh and uncaring.

If we wish to think seriously about how best to live, the question that Grace Jantzen posed for the discipline is a useful one: how might the philosophies of religion we develop support human flourishing? Rather than shy away from this question, philosophers of religion should rise to its challenge, for we are well-placed to engage with the problems that beset our age: poverty; the affects of impersonal markets on

\footnotetext{
${ }^{20}$ We might want to expand that notion of flourishing to include that of other animals and the planet itself: see Goodchild 2002.
} 
individuals and communities; the self-interest promoted by consumer capitalism; the looming global disaster of climate change. Through the study of evil we can help develop a form of discourse and a kind of practice that enables better ways of living, based upon an appreciation of the importance of finding fresh ways of orientating ourselves to others and the world. 


\section{Bibliography}

Adams, M. M. (1999), Horrendous Evils and the Goodness of God, New York: Cornell University Press.

Arendt, H. (1963), Eichmann in Jerusalem, London: Penguin.

Arendt, H. ([1948] 1968), The Origins of Totalitarianism, New York: Harcourt.

Beauvoir, S de ([1949] 1972), The Second Sex, Harmondsworth: Penguin.

Baehr, P. (2000), The Portable Hannah Arendt, Harmondsworth: Penguin.

Bernstein, R. (2002), Radical Evil: A Philosophical Interrogation, Cambridge: Polity.

Bonhoeffer, D. ([1953] 1971), Letters and Papers from Prison, London: SCM.

Bourdieu, P. et al (1999), The Weight of the World: Social Suffering in Contemporary Society, Cambridge: Polity.

Clack, B. (1999), Misogyny in the Western Philosophical Tradition, London: Routledge.

Clack, B. (2005), 'Distortion, Dishonesty and the Problem of Evil' in H. M. Vroom, Wrestling with God and with Evil, Amsterdam: Rodopi.

Clack, B. (2013), 'Feminism and the Problem of Evil' in J P McBrayer and D. Howard-Snyder, The Blackwell Companion to the Problem of Evil, Oxford: Blackwell, pp. 326-339.

Davis, S. T. (2001), 'Free Will and Evil' in S. T. Davis, editor, Encountering Evil, $2^{\text {nd }}$ edition, Louisville: WJK, pp. 73-89.

Evans, G. (2006), Educational Failure and Working Class White Children in Britain, London: Palgrave Macmillan.

French, M. (1992), The War Against Women, London: Hamish Hamilton.

Freud, E. L., ed. (1960), Letters of Sigmund Freud, tr. T and J. Stern, New York: Basic Books. 
Freud, S. (1916-1917), Introductory Lectures on Psycho-Analysis, SE 15 \& 16.

Goodchild, P. (2002), Capitalism and Religion: The Price of Piety, London:

Routledge

Hadot, P. (1995), Philosophy as a Way of Life, Oxford: Blackwell

Howie, G. (2010), Between Feminism and Materialism, London: Palgrave Macmillan.

Jantzen, G. (1998), Becoming Divine: Towards a Feminist Philosophy of Religion, Manchester: Manchester University Press.

Klein, M. (1946), 'Notes on Some Schizoid Mechanisms' in Melanie Klein Envy and Gratitude and Other Works, 1946-1963, London: Vintage, pp. 1-24.

Kynaston, D. (2007), Austerity Britain 1945-51, London: Bloomsbury.

Le Doeuff, M. (2003), The Sex of Knowing, New York: Routledge.

Lloyd, G. (1984), The 'Man' of Reason, London: Methuen.

Midgley, M. ([1984] 2001), Wickedness, London: Routledge.

Marx, K. (1844), 'Critique of Hegel's Philosophy of Right' in John Raines, ed. (2002), Marx on Religion, Philadelphia: Temple University Press, pp. 170182.

Marx, K. (1845), 'Concerning Feuerbach' in John Raines, ed. (2002), Marx on Religion, Philadelphia: Temple University Press, pp. 182-184.

McGhee, M. (2000), Transformations of Mind: Philosophy as Spiritual Practice, Cambridge: CUP.

Moltmann, J. (1974), The Crucified God, London: SCM.

Nietzsche. F. ([1887] 2001), The Gay Science. Cambridge: Cambridge University Press.

Nussbaum, M. (1996), The Therapy of Desire: Theory and Practice in Hellenistic Ethics, Princeton: Princeton University Press. 
Okin, S. M. (1979), Women in Western Political Thought, Princeton: Princeton University Press

Phillips, D.Z. (1988), 'On Not Understanding God' in D.Z. Phillips, editor, Wittgenstein and Religion, London: Macmillan, 1993, pp. 153-170.

Plantinga, A. (1977), God, Freedom, and Evil, Grand Rapids, MI: Eerdmans.

Plumwood,V. (1993), Feminism and the Mastery of Nature, London: Routledge.

Roth, J. (2001), 'Critique of S. T. Davis' in S. T. Davis, editor, Encountering Evil, $2^{\text {nd }}$ edition, Louisville: WJK, pp. 97-101.

Ruether, R.R. (1983), Sexism and God-Talk, London: SCM.

Seneca, L.A. (1969), Letters from a Stoic, London: Penguin.

Spark, M. ([1963] 2013), The Girls of Slender Means, London: Penguin.

Stump, E. (2010), Wandering in Darkness: Narrative and the Problem of Suffering, Oxford: OUP.

Surin, K. (1986), The Problem of Evil, Oxford: Blackwell.

Tilley, T. (1991), The Evils of Theodicy. Georgetown: Georgetown University Press.

Villa. D. (1996), 'The Banality of Philosophy: Arendt on Heidegger and Eichmann' in L. May \& Kohn. J., editors, Hannah Arendt: Twenty Years Later, Cambridge: MA: MIT Press, pp. 179-196.

Weber, M. (1947), Theory of Social and Economic Organisation, London: Macmillan.

Welch, S. (1990), A Feminist Ethic of Risk, Minneapolis: Fortress Press.

Williams, B. (1981), Moral Luck, Cambridge: CUP. 